This item was submitted to Loughborough's Research Repository by the author.

Items in Figshare are protected by copyright, with all rights reserved, unless otherwise indicated.

\title{
A review on electronic bio-sensing approaches based on non-antibody recognition elements
}

PLEASE CITE THE PUBLISHED VERSION

http://dx.doi.org/10.1039/C5AN02623G

PUBLISHER

(C) RSC

VERSION

AM (Accepted Manuscript)

PUBLISHER STATEMENT

This work is made available according to the conditions of the Creative Commons Attribution-NonCommercialNoDerivatives 4.0 International (CC BY-NC-ND 4.0) licence. Full details of this licence are available at: https://creativecommons.org/licenses/by-nc-nd/4.0/

\section{LICENCE}

CC BY-NC-ND 4.0

\section{REPOSITORY RECORD}

Chen, Hu, Jingfeng Huang, Alagappan Palaniappan, Yi Wang, Bo Liedberg, Mark Platt, and Alfred I.Y. Tok. 2019. "A Review on Electronic Bio-sensing Approaches Based on Non-antibody Recognition Elements". figshare. https://hdl.handle.net/2134/20920. 


\title{
Journal Name
}

\section{ARTICLE}

\section{A review on electronic bio-sensing approaches based on non- antibody recognition elements}

Received 00th January 20xx, Accepted 00th January 20xx

DOI: $10.1039 / x 0 x \times 00000 x$

www.rsc.org/

\author{
Hu Chen, ${ }^{\text {a,b,d }}$ Jingfeng Huang, ${ }^{\text {a,b }}$ Alagappan Palaniappan, ${ }^{c}$ Yi Wang, ${ }^{c}$ Bo Liedberg, ${ }^{a, c}$ Mark Platt, ${ }^{d, *}$ \\ and Alfred ling Yoong Tok ${ }^{a, b, *}$
}

\begin{abstract}
In this review, recent advances on the development of electronic detection methodologies based on non-antibody recognition elements such as functional liposomes, aptamers and synthetic peptides are discussed. Particularly, we highlight the progress of field effect transistor (FET) sensing platforms where possible as the number of publications on FET-based platforms has rapidly increased. Biosensors involving antibody-antigen interactions have been widely applied in diagnostics and healthcare in virtue of superior selectivity and sensitivity, which can be attributed to their high binding affinity and extraordinary specificity, respectively. However, antibodies are typically suffering from fragile and complicated functional structures, large molecular size and sophisticated preparation approaches (resource-intensive and timeconsuming), resulting in limitations such as short shelf-life, insufficient stability and poor reproducibility. Recently, biosensing approaches based on synthetic elements have been intensively explored-in to contrast to existing reports, this review provides a comprehensive overview on recent advances in development of biosensors utilizing synthetic recognition elements and a detailed comparison of their assay performances. Therefore, this review would serve as a good summary of the efforts on development of electronic bio-sensing approaches involving synthetic recognition elements.
\end{abstract}

\section{Introduction}

As analytical devices used for detections of various biological analyte, ${ }^{1}$ biosensors have been extensively investigated and applied in various fields such as environmental protection, ${ }^{2,3}$ food safety, ${ }^{4,5}$ and healthcare. ${ }^{6-8}$ Due to the great achievements in this field, the world market for commercial biosensors reached 12 billion US dollars in 2011 and is expected to exceed 16 billion US dollars in 2018. ${ }^{1}$ Among all sensing approaches reported, assays based on electronic platforms have attracted increasing attention. The number of articles referencing 'electronic biosensor' published in a year has been increasing steadily over the past decade (Fig. 1a). Particularly, assays using field-effect transistor (FET) sensing platforms have been intensively studied and widely applied in virtue of their superior sensitivity, ${ }^{9,10}$ good compatibility with microfabrication processes, ${ }^{11}$ and potential for miniaturization. ${ }^{\mathbf{1 2}}$ Indeed, over $40 \%$ of all articles related to

\footnotetext{
School of Materials Science and Engineering, Nanyang Technological University,

Singapore 639798. E-mail: miytok@ntu.edu.sg; Tel: +65 67904953.

b. Institute for Sports Research, Nanyang Technological University, 50 Nanyang

Avenue, Singapore 639798.

Centre for Biomimetic Sensor Science, 50 Nanyang Drive, Singapore 637553,

Singapore.

d. Department of Chemistry, Centre for Analytical Science, Loughborough University,

Loughborough, Leicestershire LE11 3TU, UK. E-mail: m.platt@lboro.ac.uk; Tel: +44 (0) 1509222573

+ Footnotes relating to the title and/or authors should appear here.

Electronic Supplementary Information (ESI) available: See DOI: 10.1039/x0xx0000
}

electronic biosensors involved FET-based platforms and publications referencing 'FET biosensor' exceeded 3500 in 2014. The general configuration of a FET device (Fig. 1b) includes a source electrode, a drain electrode and a gate electrode. The current from source to drain $\left(I_{d}\right)$ is modulated by the voltage on gate $\left(\mathrm{V}_{\mathrm{g}}\right)$. In FET sensing processes, molecular binding events in the gate region leads to a change in the conductance of the transducing layer, which could be correlated to the concentration of analytes. ${ }^{13}$

Conventionally, most sensing approaches are based on natural biomolecular pairs such as antibody/antigen due to their superior binding affinity and selectivity. ${ }^{14,15}$ Biosensors based on these approaches have been intensively studied and widely applied in diagnostics and healthcare. Nevertheless, several limitations have also been observed for the sensing approaches based on natural biomolecular pairs. Firstly, the functional structures of natural biomolecules such as antibodies are typically complicated and fragile. Hence, denaturation/deactivation of these molecules can be readily triggered by exposure to typical working environments of biosensors. ${ }^{16}$ Meanwhile, these natural biomolecules usually exhibit large molecular sizes, which may significantly contribute to steric hindrance of target molecules in the sensing process. ${ }^{17,18}$ Large molecular size further limits the quantity of receptors immobilized per unit area. ${ }^{19}$ Additionally, preparations of natural biomolecules are typically resourceintensive and time-consuming, resulting in high cost of 
biosensors based on these approaches. ${ }^{20}$ Therefore, practical applications of biosensors based on natural biomolecular pairs have been limited by issues such as short shelf-life, insufficient stability and poor reproducibility. Over the past few decades, efforts have been devoted to exploration of sensing approaches that are not based on conventional natural biomolecular pairs.

To date, a variety of synthetic molecules have been proposed as alternative recognition elements to the natural biomolecules in conventional bio-sensing assays. Among these options, liposomes, ${ }^{21}$ aptamers ${ }^{22}$ and peptides ${ }^{23}$ have been intensively explored and widely applied. In response to increasing attentions to alternative recognition elements, several reviews summarizing biosensors based on synthetic recognition elements have been published. ${ }^{16,}{ }^{23-25}$ These articles summarized advances in the study of detection mechanism, described recent cases and typically included comparisons of detection methodologies such as electronic methods, optical methods, quartz crystal microbalance-based methods, utilizing one particular class of synthetic recognition element. However, a comprehensive summary of assay performances of different synthetic recognition elements would be necessary for the evaluation of their applicability for biosensing. This article therefore offers an overview of the development of electronic biosensors based on non-antibody recognition elements. More specifically, the most recent advances on different categories of non-antibody recognition elements (including liposomes, aptamers and peptides) were highlighted, followed by individual discussions on the development of electronic biosensors based on each category of non-antibody recognition elements. Meanwhile, biosensors based on different categories of non-antibody recognition elements were compared with each other to facilitate understanding of their respective pros and cons. Table 1 summarizes recent advances in sensing assays based on recognition elements mentioned above. The target analyte, limit of detection achieved, methodology used and characteristics of these assays are presented. Table 1 illustrates that, irrespective of the methodology adopted, assays based on synthetic recognition elements have exhibited the capability to detect various analytes (including enzyme, virus, DNA and bacteria) at clinically relevant concentrations. a

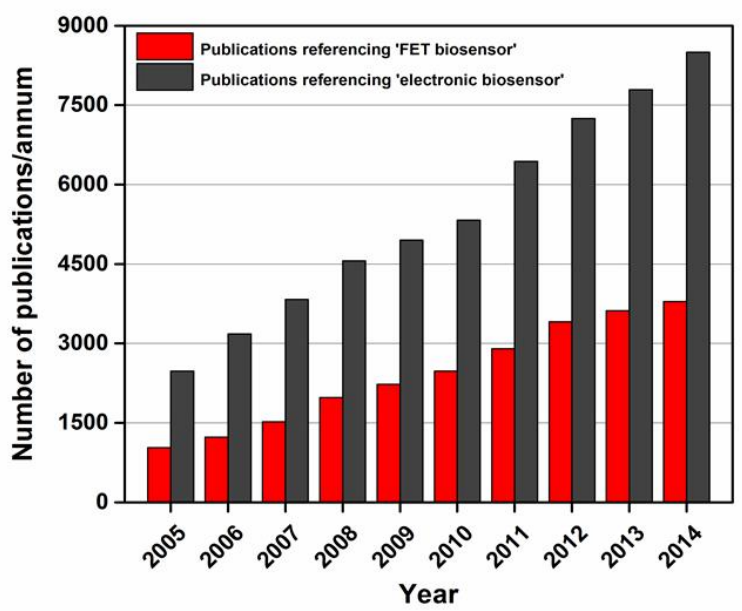

b

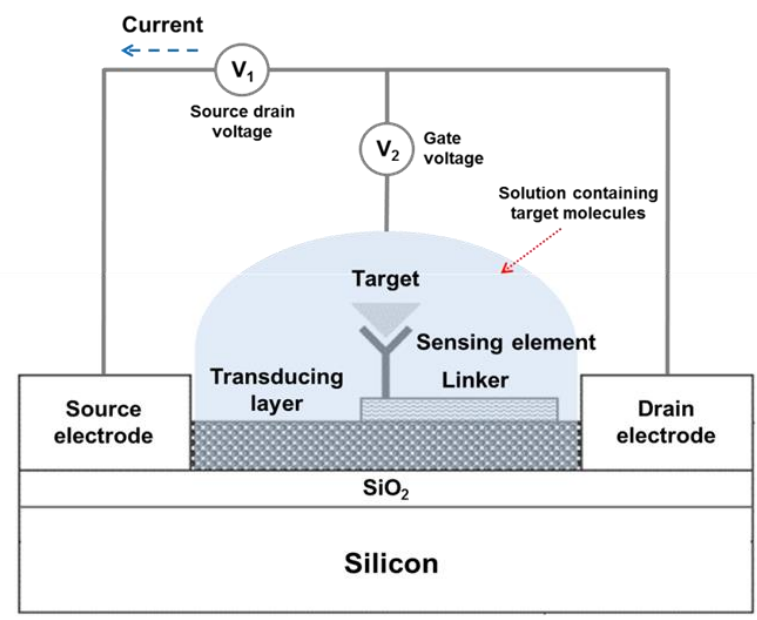

Fig. 1 (a) A search of publications referencing 'electronic biosensor' and 'field-effect transistor biosensor' over the past decade, using Google Scholar. Steady increases have been observed for both topics. The publications related to electronic biosensors exceeded 8000 in 2014 and around $40 \%$ of these studies involved FET-based sensing platforms. (b) General configuration of an FET-based sensing platform. Capture of analyte by the recognition element can generate a change in the source-drain current or potential, which can be detected as a signal. 


\section{Journal Name}

ARTICLE

Table 1. A comparison of various synthetic recognition elements (liposomes, aptamers and peptides) for electronic bio-sensing applications

\begin{tabular}{|c|c|c|c|c|}
\hline $\begin{array}{l}\text { Recognition } \\
\text { elements }\end{array}$ & Target analyte & Limit of detection & Methodology & Characteristics \\
\hline \multirow[t]{6}{*}{ Liposomes } & $\begin{array}{l}\text { Human immunodeficiency } \\
\text { virus }^{26} \\
\text { Nuclei acid sequences }{ }^{27}\end{array}$ & $6.7 \times 10^{11} / \mu \mathrm{l}$ & Amperometric detection & $\begin{array}{l}\text { Pros } \\
\text { - Signal amplification via reporter encapsulation } \\
\text { - Rapid and label-free detection } \\
\text { - High specificity }\end{array}$ \\
\hline & Glucose ${ }^{28,29}$ & $40 \mathrm{mM}$ & Cyclic voltammetry & \multirow{5}{*}{$\begin{array}{l}\text { Cons } \\
\text { - Tedious selection and modification process } \\
\text { required }\end{array}$} \\
\hline & Glucose $^{30}$ & $8.6 \pm 1.1 \mu \mathrm{M}$ & Amperometric detection & \\
\hline & Organophosphate ${ }^{31}$ & $0.68 \pm 0.076 \mu \mathrm{g} / \mathrm{L}$ & Amperometric detection & \\
\hline & Escherichia coli (E. coli) ${ }^{32}$ & $100 \mathrm{cfu} / \mathrm{mL}$ & Amperometric detection & \\
\hline & Phospholipase $\mathrm{A}_{2}{ }^{33}$ & $80 \mathrm{pM}$ & Amperometric detection & \\
\hline \multirow[t]{10}{*}{ Aptamers } & Oligonucleotides (DNA) ${ }^{34}$ & $2-5 \mathrm{nM}$ & Potentiometric sensing & \multirow{10}{*}{$\begin{array}{l}\text { Pros } \\
\text { - Good reproducibility } \\
\text { - Excellent stability in harsh environments } \\
\text { - Reversible aptamer/target interactions } \\
\text { Cons } \\
\text { - Sensitivity to hydrolytic digestion by nucleases }\end{array}$} \\
\hline & Adenosine $^{35}$ & $50 \mu \mathrm{M}$ & Potentiometric sensing & \\
\hline & Immunoglobulin $\mathrm{E}(\mathrm{IgE})^{36}$ & $250 \mathrm{pM}$ & Amperometric detection & \\
\hline & HIV-1 Tat protein ${ }^{37}$ & $<1 \mathrm{nM}$ & Amperometric detection & \\
\hline & ATP $^{38}$ & $<10 \mathrm{nM}$ & Potentiometric sensing & \\
\hline & Adenosine $^{38}$ & $1-10 \mathrm{nM}$ & Potentiometric sensing & \\
\hline & Lysozyme $^{39}$ & $12 \mathrm{nM}$ & Potentiometric sensing & \\
\hline & Thrombin ${ }^{39}$ & $6.7 \mathrm{nM}$ & Potentiometric sensing & \\
\hline & Thrombin ${ }^{40}$ & $5.5 \mathrm{nM}$ & Potentiometric sensing & \\
\hline & Matrilysin (MMP-7) ${ }^{41}$ & $3.4 \mathrm{pM}$ & Cyclic voltammetry & \\
\hline \multirow[t]{4}{*}{ Peptides } & $\begin{array}{l}\text { Trypsin and } \alpha \text {-Thrombin } \\
\text { (protease) }^{42}\end{array}$ & $1 \mathrm{nM}$ & Cyclic voltammetry & $\begin{array}{l}\text { Pros } \\
\text { - High binding affinity } \\
\text { - Excellent stability in harsh environments }\end{array}$ \\
\hline & Escherichia coli (E. coli) ${ }^{43}$ & $100 \mathrm{cfu} / \mathrm{mL}$ & Impedance spectroscopy & - Facile and cost-effective synthesis \\
\hline & C-creative protein (CRP) ${ }^{44}$ & $0.1 \mu \mathrm{g} / \mathrm{L}$ & Impedimetric sensing & \multirow{2}{*}{$\begin{array}{l}\text { Cons } \\
\text { - Signal marker labelling required in some cases } \\
\text { - Moderate selectivity due to their semi- } \\
\text { selective nature }\end{array}$} \\
\hline & MMP-7 & $10 \mathrm{ng} / \mathrm{mL}$ & Amperometric detection & \\
\hline
\end{tabular}

\section{Liposome-based sensing approaches}

Liposomes are self-assembled microscopic vesicles prepared by the hydration of lipid thin film. ${ }^{45-47}$ As shown in Fig. 2, these artificially-prepared vesicles contain an inner aqueous compartment surrounded by a lipid bilayer (i.e. phospholipids 
and sterols), resulting in hydrophilic interior and exterior. ${ }^{48}$ Due to their unique structures, liposomes can encapsulate any water-soluble molecules or nanoparticles (e.g. enzymes, nuclei acids, chemical molecules, fluorescent dyes). In the presence of certain molecules/rays or changes in the environment, rupture of liposomes are triggered and encapsulants are released. ${ }^{49,50}$ Phospholipids, the basic units of liposomes, exhibit distinctive advantages such as non-toxicity, biodegradability and good biocompatibility. Therefore, liposomes have been applied in drug delivery (as carriers), ${ }^{51,52}$ food science, ${ }^{53}$ and bio-sensing (as recognition elements). ${ }^{33}$ Particularly, the application of liposomes in bio-sensing has attracted increasing attention. Previously, liposomes were used as carriers of optical indicators in assays based on fluorescence, ${ }^{54}$ surface plasmon resonance (SPR), ${ }^{55}$ and colorimetric changes. ${ }^{56}$ These optical approaches were facile, rapid yet effective. ${ }^{57-59}$ However, assays based on optical methodologies are inherently limited by insufficient sensitivity, cross-talk issues (especially in fluorescence-based assays) and requirement for sophisticated instrumentation. Therefore, recent efforts have been made to integrate liposomes with other detection methods. Combined with effective transduction methodologies such as electronic transductions, liposomes can be used for molecular detections with ultra-high sensitivity, ${ }^{33}$ which can be attributed to the significant signal amplification realized by appropriate reporters. ${ }^{60}$

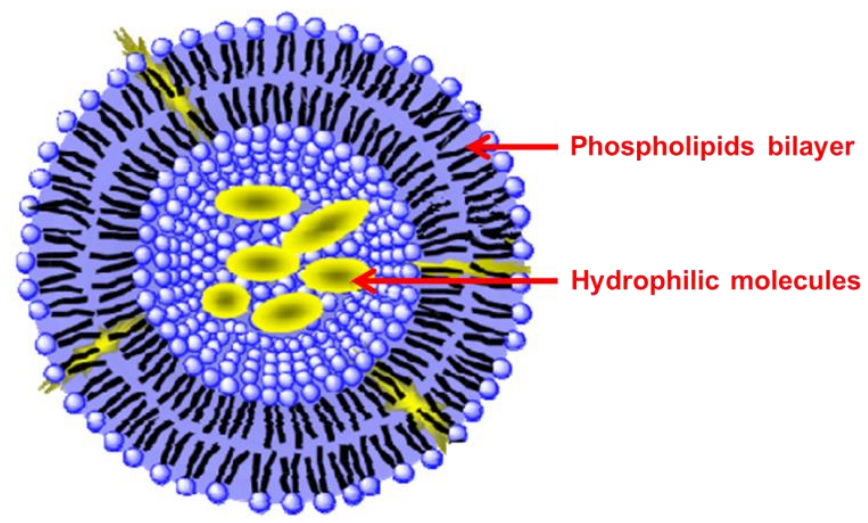

Fig. 2 Schematic illustration of unilamellar liposome. Hydrophilic molecules are encapsulated in the liposome, thus being separated from the solvent outside. (From Chen et al., ${ }^{61}$ with permission from SciencePG)

Liposome-based assays for detections of various analytes (e.g. enzymes, viruses and nuclei acids) have been reported. For instance, Damhorst et al. introduced an assay using ions as reporters. $^{26}$ In this study, ion-encapsulated dipalmitoylphosphatidylcholine (DPPC) liposomes were employed for electronic detection of viruses. In virtue of the portable impedance sensing platform used, this assay exhibited great potential for point-of-care diagnostic applications. Additionally, this assay may be adapted for viral detections using liposomes as recognition elements upon appropriate selection or modification of liposomes. Wongkaew et al. reported an amperometric detection of chemical molecules on a microfluidic channel. ${ }^{27}$ Herein, specific nuclei acid sequences were measured quantitatively using ferri/ferro hexacyanideencapsulated liposomes. Fast (within $5 \mathrm{~min}$ ) and sensitive (LOD $=12.5 \mu \mathrm{M}$ ), this assay is suitable for diagnostics and healthcare applications. Taylor et al. presented an assay for quantitative detection of glucose using a liposomal enzyme electrode. Glucose oxidases were encapsulated in liposomes and the glucose molecules were detected using a cyclic voltammetry related methodology. A linear response to glucose up to 40 $\mathrm{mM}$ was achieved using this assay (Fig. 3a). ${ }^{28}$ Similarly, Graça et al. presented an amperometric glucose biosensor based on glucose oxidase (GOx)-encapsulated liposomes. ${ }^{30}$ Herein, GOx were encapsulated in liposomes to preserve their native structures (Fig. 3b). The sensitivity of this assay was 7.5 times higher than that of its peers using non-encapsulated GOx. Additionally, the proposed assay showed a sensitivity that was significantly higher than previous assays. Yan et al. described an assay for detections of organophosphate pesticides residues. ${ }^{31}$ In this assay, acetylcholinesterase (AChE) molecules were encapsulated in phosphatidylcholine liposomes and the porin-embedded lipid membrane allows in pesticide only. The current change was generated by the inhibition reaction of organophosphate pesticides by AChE. Nevertheless, liposomes were not functioning as recognition elements in assays mentioned above. Instead, they were either used as carriers (to screen out other molecules or preserve the natural structure of encapsulants) or tagged with a reporter probe that hybridizes with the target.

More recently, efforts have been made to explore the capability of liposome as recognition element in electronic detections. Zhang et al. reported an amperometric detection of Escherichia coli (E. coli) using 4-nitrophenyl $\beta$-D-glucuronide (PNPG) as the recognition element. ${ }^{32} \beta$-D-glucuronide released from E. coli catalysed the hydrolysis of PNPG to produce 4nitrophenyl and the concentration of these electroactive molecules is proportional to that of E. coli. Detection of E. coli ranging from $1.5 \times 10^{2}$ to $1.0 \times 10^{6} \mathrm{cfu} / \mathrm{mL}$ was demonstrated and the LOD achieved was $100 \mathrm{cfu} / \mathrm{mL}$. Chen et al. reported a liposome-based enzymatic assay for the detection of phospholipase $A_{2}$ (Fig. 3c). ${ }^{33}$ In this assay, 2,4,6-trinitrophenol molecules (TNPs, used as reporter) were encapsulated in 1palmitoyl-2-oleoyl-sn-glycero-3-phosphatidylcholine (POPC) liposomes. In the presence of target enzymes, rupture of liposomes was triggered and the reporter molecules were released. Once diffused to the surface of reduced graphene oxide ( $r G O)$, TNPs adsorb on rGO via $\pi-\pi$ interactions and modulate the conductance of the transducing layer due to the presence of electron withdrawing $\mathrm{NO}_{2}$ groups. ${ }^{62}$ Besides the sensitive nature of electronic biosensors, signal enhancement by the excess concentration of reporter molecules encapsulated also made a great contribution to the superior sensitivity of this assay. Additionally, this approach could be extended for detections of other lipid-degrading enzymes or membrane toxins.

Nevertheless, it is notable that liposomes suffer from tedious selection and modification process. ${ }^{45}$ and many liposome- 

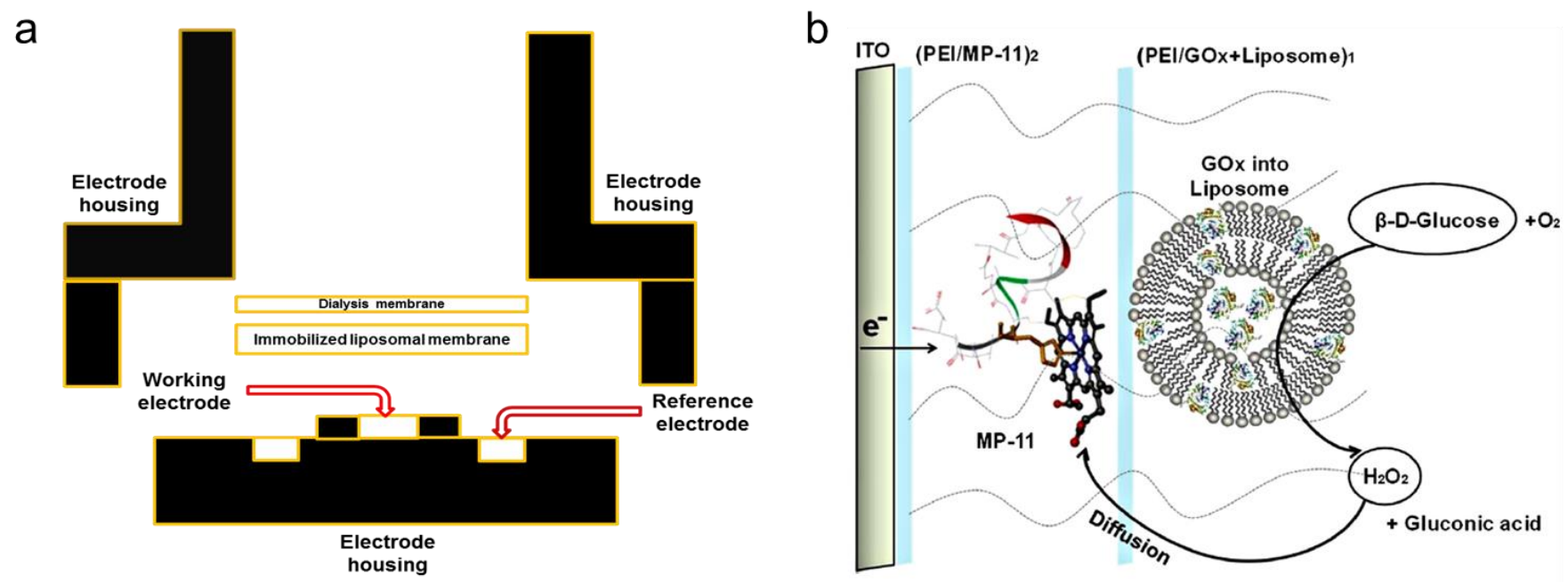

C
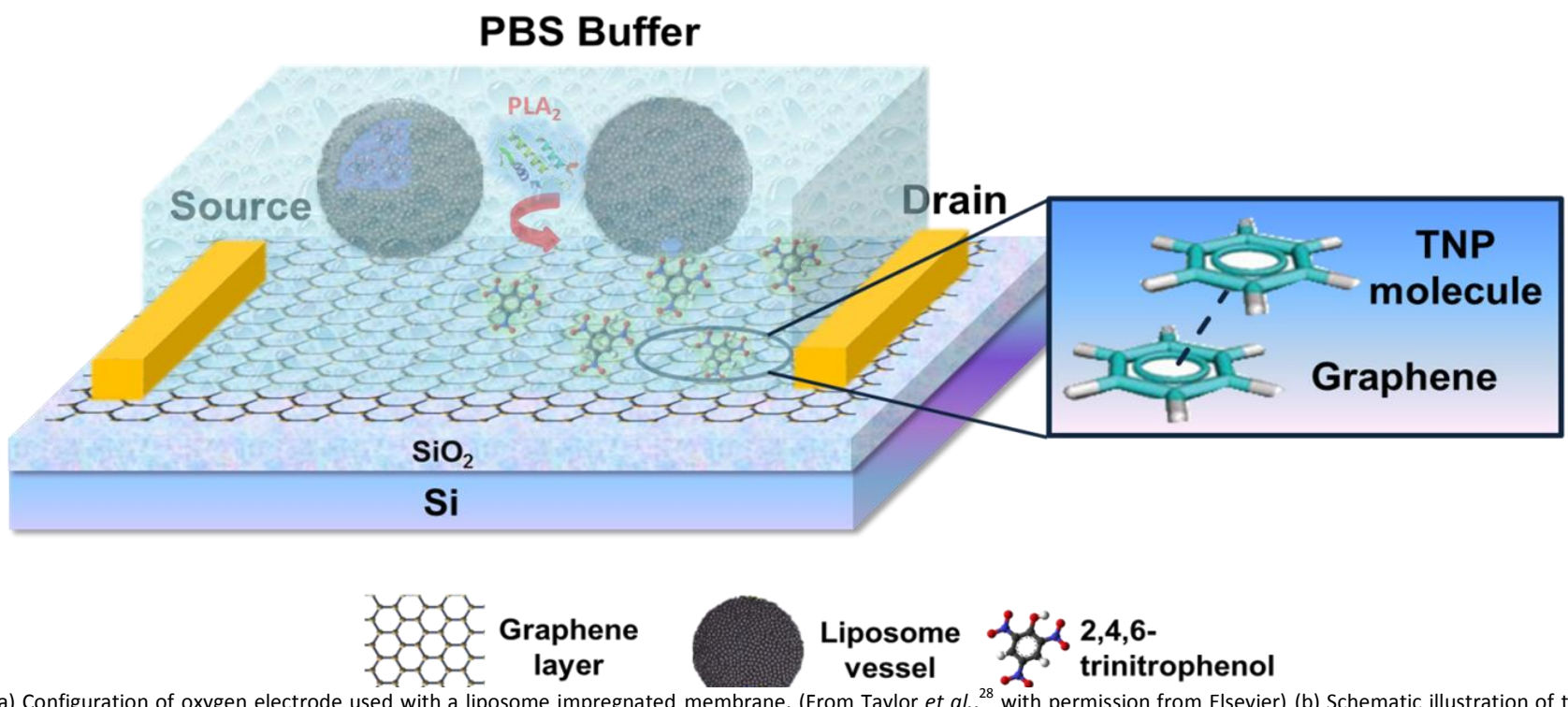

Fig. 3 (a) Configuration of oxygen electrode used with a liposome impregnated membrane. (From Taylor et al., ${ }^{28}$ with permission from Elsevier) (b) Schematic illustration of the detection mechanism involved in amperometric glucose biosensor based on glucose oxidase (GOx)-encapsulated liposomes. (From Graça et al., ${ }^{30}$ with permission from Elsevier) (c) Reporter-encapsulated POPC liposomes on reduced graphene oxide based field-effect transistor (FET). Rupture of liposomes, which is triggered by the target enzyme, leads to release of TNP molecules, which then adsorb on graphene surface and modulate $\mathrm{I}_{\mathrm{d}}$. (From Chen et al., ${ }^{33}$ with permission from Royal Society of Chemistry)

\section{Aptamer-based sensing approaches}

In bio-sensing applications, aptamers are defined as selected single-stranded nucleic acid ligands (DNA or RNA) with high binding affinity and specificity to the target analyte (e.g. protein and inorganic molecules). ${ }^{63,64}$ Attributed to the folding capability upon binding, ${ }^{65}$ the binding affinity and specificity of aptamer/target interactions are comparable to that of antibody/antigen interactions. Hence, nucleic acid aptamers are termed as "chemical antibodies" in various cases. ${ }^{66,67}$ In virtue of unprecedented advantages over natural receptors, aptamers have attracted increasing attention in diagnostics and healthcare. ${ }^{68-71}$ For instance, most aptamer-based biosensors exhibit good reproducibility thanks to the wellestablished chemical synthesis routes. $^{24}$ Currently, most aptamers are obtained by the systematic evolution of ligands by exponential enrichment (SELEX) process (Fig. 4). ${ }^{72,73}$ Firstly, a huge nuclei acid library is created and incubated with the target molecule/ligand. The unbound sequences and molecules are removed, while the bound nuclei acids are eluted and amplified by polymerase chain reaction (PCR). As a result, an enriched library is obtained and this new library is used as the starting library in the next cycle. After 6-12 consecutive cycles, the final library is cloned and sequenced. ${ }^{24,}$ ${ }^{74}$ The in vitro selection of aptamers eliminates the need for in vivo immunization of animals, as in the case of antibody production. Additionally, aptamers can be chemically synthesized in an easy and reproducible manner once the sequence is obtained using SELEX. Unlike natural biomolecules, aptamers exhibit excellent stability in harsh environments and are not subject to denaturization, thus suitable for clinical 
applications. ${ }^{75}$ More importantly, significant conformational changes can be observed for aptamers upon target binding, demonstrating great potential for ultra-sensitive assays. ${ }^{24,76}$ Interactions between aptamers and target molecules could be reversed by reversible intermolecular hybridizations, ${ }^{77}$ indicating a great potential for development of non-disposable biosensors. Additionally, non-specific adsorptions on nucleic acid interfaces are usually reduced compared with protein interfaces.

Nevertheless, it should be noted that aptamers, especially RNA ones, are readily digested by nucleases. ${ }^{78}$ Therefore, it is necessary to reduce concentrations of nucleases to negligible levels for proper functioning of aptamer-based assays.

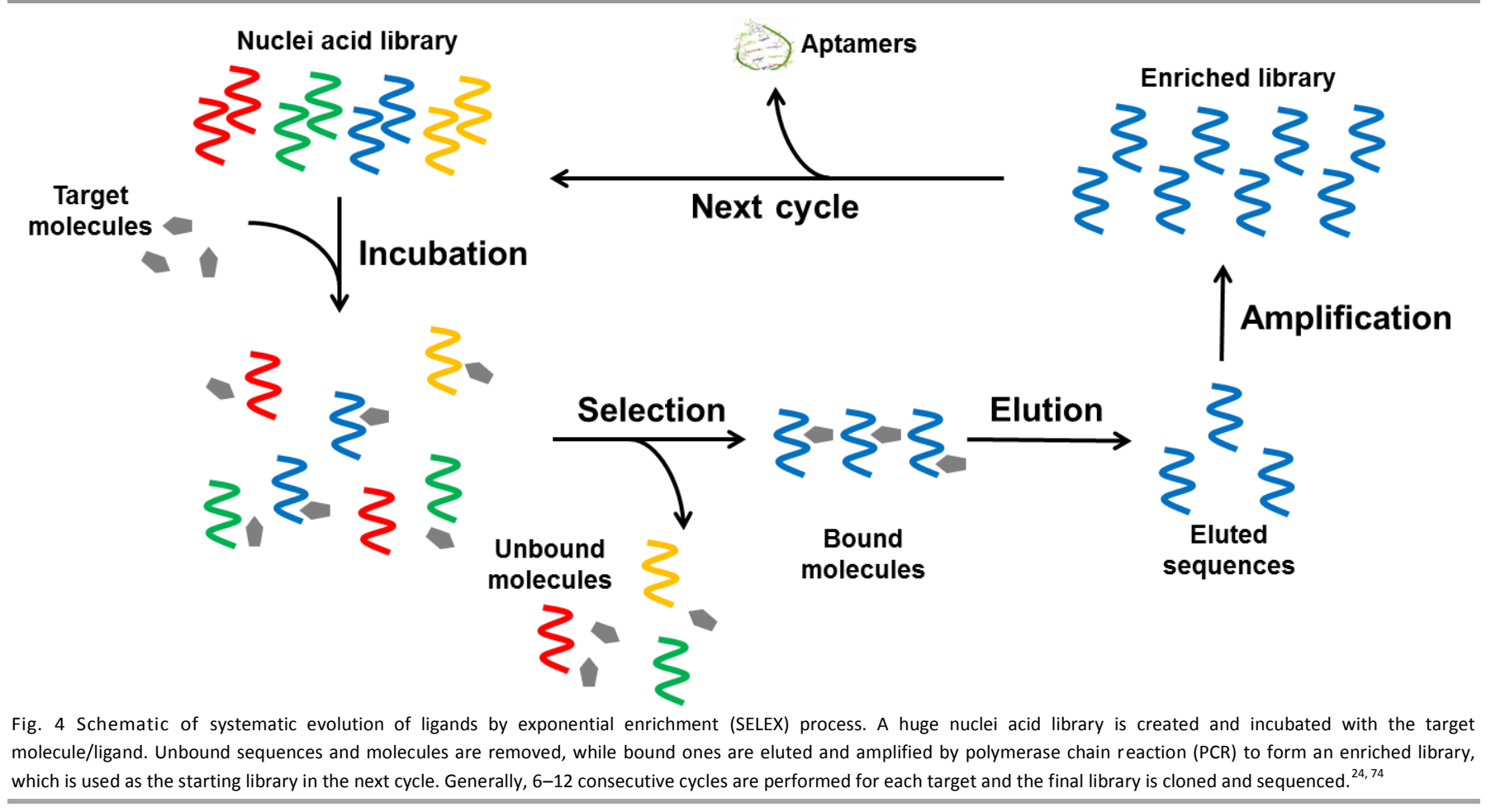

To date, aptamers-based assays have been intensively explored and widely applied. Fritz et al. described an ultraselective and label-free assay for DNA detection. ${ }^{34}$ Herein, complementary DNA sequences adsorbed on micro-fabricated FET were used as the recognition element. The LOD achieved by this assay was 2-5 nM. Additionally, this assay achieved the detection of a single base mismatch within 12-mer oligonucleotides, demonstrating excellent specificity. Zayats et al. monitored the binding of adenosine (molecule with a relatively low molecular weight) to its corresponding aptamer. $^{35}$ An amino-functionalized nucleic acid (named nucleic acid 5 in the study) was used as the aptamer and another nucleic acid (named nucleic acid 6 in the study) was hybridized with the aptamer. The introduction of adenosine triggered the displacement of nucleic acid 6, resulting in changes of the local charge associated with the gate potential (Fig. 5a). This assay exhibited high specificity (negligible responses to other nucleotides such as cytidine), while the sensitivity was relatively poor (detection limit $=50 \mu \mathrm{M}$ ). Maehashi et al. reported an aptamer-modified carbon nanotube field-effect transistor (CNT-FET) for the detection of immunoglobulin $\mathrm{E}(\mathrm{IgE}) .^{36}$ The introduction of $\operatorname{IgE}$ caused a significant $I_{d}$ decrease, whose magnitude was proportional to the concentration of IgE. The LOD achieved by this assay was $250 \mathrm{pM}$. Additionally, this study demonstrated the improved sensing performance of aptamer-modified devices compared with antibody-modified devices under similar experimental conditions. The higher sensitivity of aptamer-modified devices can be attributed to the small size of aptamers, which enables a larger effect of bound IgE molecules on the equilibrium distribution of mobile carriers in the carbon nanotubes by reducing the distances between IgE molecules and the nanotubes to a level below the Debye length (Fig. 5b). ${ }^{79,80}$ However, none of these studies involved clinical sample detection, which is essential for diagnostic applications. Ruslinda et al. demonstrated the detection of human immunodeficiency virus type 1 Trans-activator transcription (HIV-1 Tat protein) in clinical samples using an FET-based sensor with RNA aptamers as the recognition element (Fig. 5c). ${ }^{37}$ Incubations with HIV-1 Tat protein at concentrations of $100 \mathrm{nM}, 10 \mathrm{nM}$ and $1 \mathrm{nM}$ resulted in $91 \mathrm{mV}, 49 \mathrm{mV}$ and $20 \mathrm{mV}$ of gate potential shifts in the negative direction, indicating that quantitative measurements were feasible and LOD of this assay was beyond $1 \mathrm{nM}$. Additionally, the RNA aptamer was demonstrated to be highly specific to the target and cyclic detections were achieved, demonstrating the reusability of the proposed sensor.

More recently, Goda et al. conducted a series of studies in the field of FET-based biosensors using aptamers as the 
recognition element. In 2012, an assay using aptamerfunctionalized FET sensor with a gold electrode as extended gate was reported. ${ }^{38}$ As a proof-of-concept, detections of adenosine triphosphate (ATP) and adenosine using hairpinstructured DNA aptamers were demonstrated. Capture of the target molecules led to a structural switching of the aptamer from closed loop to open-loop conformations and the release of the preloaded DNA binder (DAPI, positively charged) into the solution (Fig. 6a). The sensitivities achieved for ATP (below $10 \mathrm{nM})$ and adenosine (1-10 nM) were significantly improved compared with previous assays. The detection of protein molecules using a similar platform was also demonstrated. ${ }^{39}$ Herein, binding of intrinsically charged target protein led to an alteration in the density of charges at the gate/solution interface (Fig. 6b). Label-free detections of lysozyme and thrombin in the dynamic ranges of $15.2-1040 \mathrm{nM}$ and $13.4-$ $1300 \mathrm{nM}$ were demonstrated. The LOD achieved for lysozyme and thrombin were $12.0 \mathrm{nM}$ and $6.7 \mathrm{nM}$, respectively. More recently, studies revealed that multiple-contact configurations could improve the binding affinity between protein and aptamers. ${ }^{81}$ Therefore, Goda et al. developed a novel aptamerfunctionalized potentiometric biosensor with improved affinity for the target protein (Fig. 6c). ${ }^{40}$ In this assay, two different aptamers that recognize different epitopes in thrombin were immobilized (in parallel or serial manners) on the sensing surface to capture the target via multiple contacts. As a result, the sensitivity of this assay was further enhanced (LOD $=5.5$ $\mathrm{nM}$ ) compared to previous reports. a

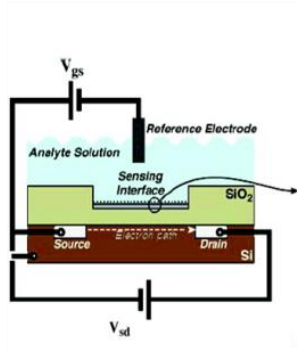

b
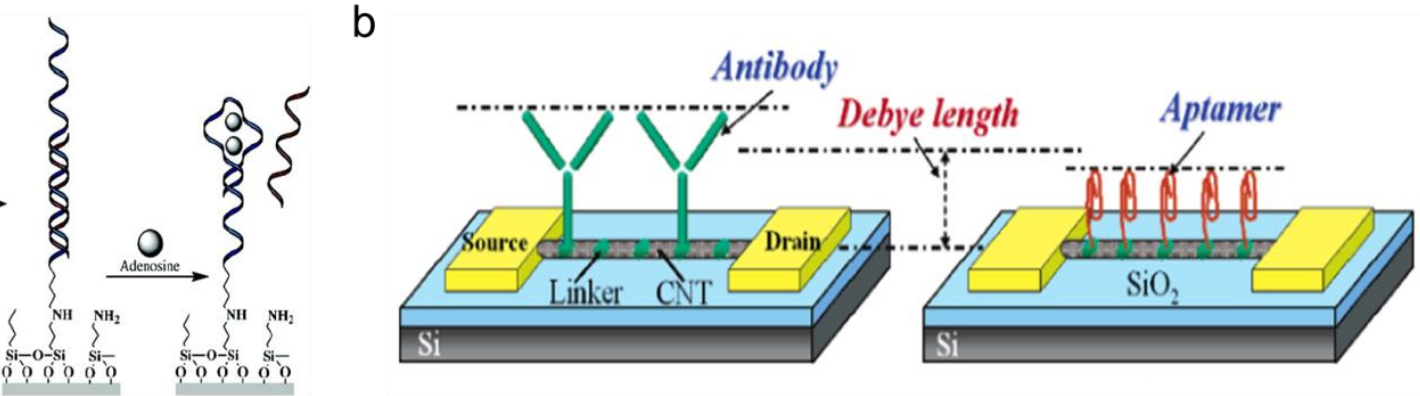

C

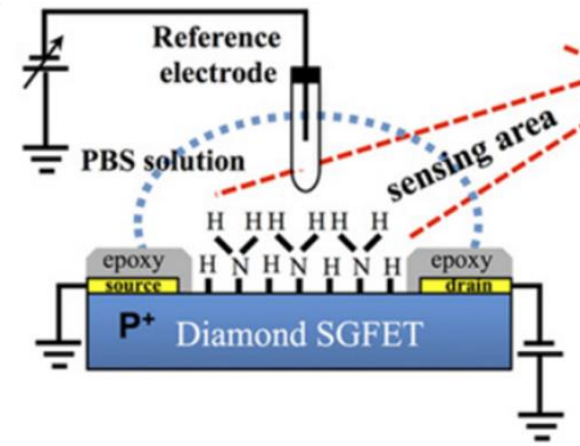

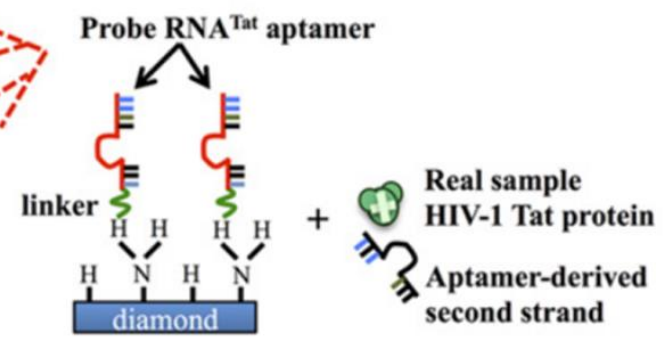

Immobilized RNA ${ }^{\text {Tat }}$ aptamer on diamond using a linker molecule

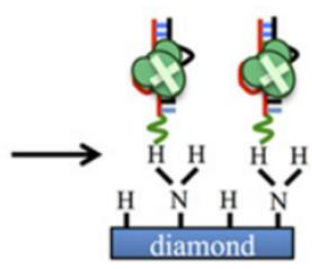

RNA aptamers form a duplex structure in the presence of Tat protein

Fig. 5 (a) FET-based aptasensor for adenosine. An amino-functionalized nucleic acid (named nucleic acid 5 in the study) was used as an aptamer for adenosine and another nucleic acid (named nucleic acid 6 in the study) was hybridized with the aptamer to amplify the signal. (From Zayats et al., ${ }^{35}$ with permissions from American Chemical Society) (b) Aptamer modified CNT-FET sensor for the detection of immunoglobulin E (IgE). The smaller size of aptamer enables a significant effect of bound proteins on the equilibrium carrier distribution in the nanotubes as the distances between these molecules and nanotubes were less than the Debye length (From Maehashi et al., ${ }^{36}$ with permissions from American Chemical Society) (c) Changes in gate potential induced by detection of HIV-1 Tat protein in real samples on diamond FET in $1 \mathrm{mM}$ PBS (pH = 7.4). (From Ruslinda et al., ${ }^{37}$ with permissions from Elsevier) 
a

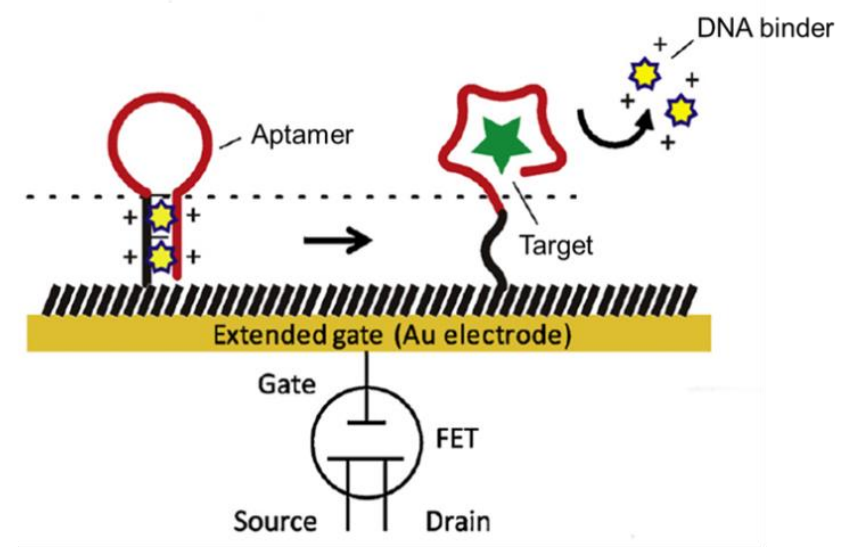

b

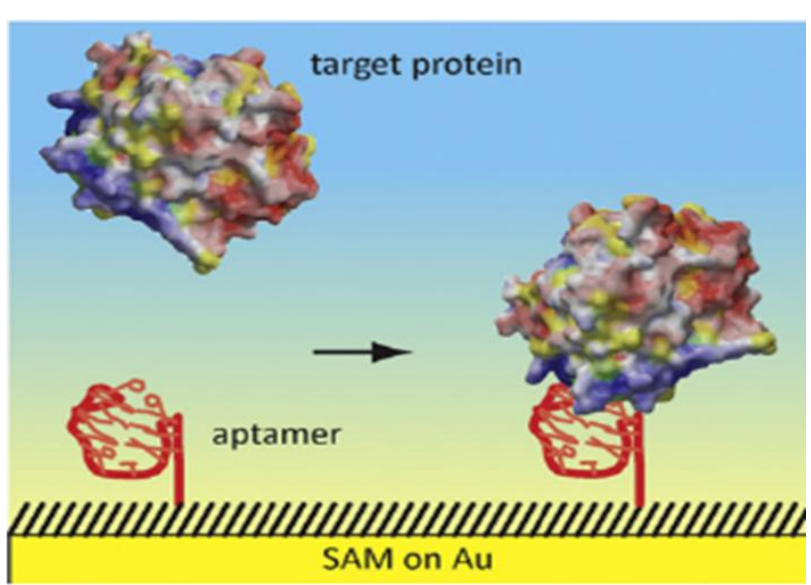

C

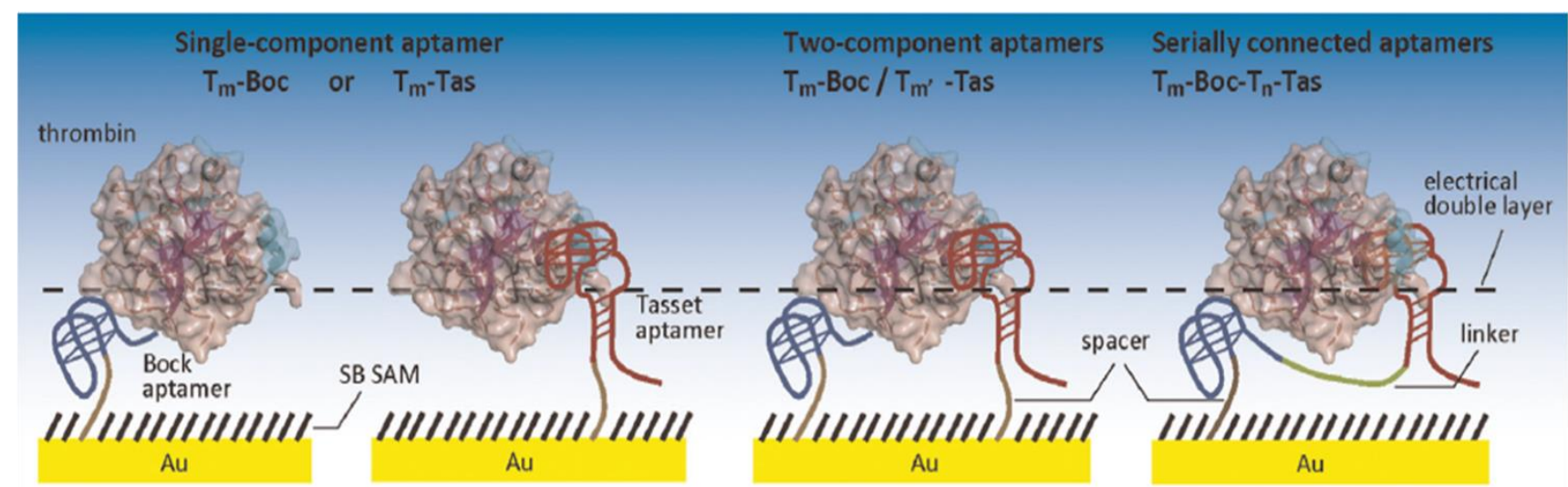

Fig. 6 (a) Conformational switching of the short hairpin (sh)-aptamer accompanied by the release of the cationic DNA binder upon detection of ATP on an FET-based sensing platform. (From Goda et al., ${ }^{38}$ with permissions from Elsevier) (b) Aptamer-induced binding of protein target (e.g. lysozyme and thrombin) in an electrical double layer at the gatesolution interface. (From Goda et al., ${ }^{39}$ with permissions from Elsevier) (c) Electrical thrombin sensing using dual aptamer surfaces. Improved affinity between aptamers and thrombin due to multiple binding contacts results in enhanced sensitivity. (From Goda et al., ${ }^{40}$ with permissions from Elsevier)

\section{Peptide-based sensing approaches}

As short chains of amino acid oligomers linked by peptide bonds, peptides have the same building blocks as proteins. Hence, these molecules have been used to substitute for proteins for clinical and diagnostic applications. ${ }^{82-84}$ Indeed, peptide-based biosensors have been proposed for detections of various targets, including cells, ${ }^{43}$ proteins, ${ }^{85}$ ions ${ }^{86}$ and small molecules. ${ }^{87,88}$ Distinctive advantages over natural molecules and other synthetic receptors have been reported for peptides. Primarily, peptides exhibit high affinity to particular analytes, ${ }^{89}$ which can be attributed to their protein-like nature as multiple interactions can be observed in most binding sites of peptides. The high affinity allows the development of ultra-sensitive and highly specific peptide-based biosensors. Moreover, the affinity can be further enhanced by easy modifications of the peptides. $^{90}$ Meanwhile, peptides have shown excellent intrinsic stability in harsh environments (e.g. in the presence of chemical and thermal denaturants). Indeed, peptides are significantly superior to proteins in terms of chemical and conformational stability due to their short-chain structures. ${ }^{91}$ As a result, peptide-based biosensors exhibit significantly increased shelf-life compared with antibody-based ones. Also, peptide-based biosensors exhibit a great potential for multiplexed detection. ${ }^{43}$ In virtue of various matured protocols that have been reported, peptides can be chemically synthesized in a facile yet cost-effective way once the sequence information is isolated from the phage display (Fig. 7). ${ }^{92,93}$

Nevertheless, it should be noted that conjugation of a reporter is typically required as peptides do not directly generate a measurable signal in response to a binding event in most assays reported. ${ }^{23}, 90$ In other words, label-free detection would be an inherent challenge for peptide-based sensing assays. Additionally, the selectivity of assays with peptides as recognition elements needs to be optimized due to the semiselective binding nature of peptides. ${ }^{94,95}$ Indeed, many peptides have exhibited significant binding affinity towards several different cells/molecules. 


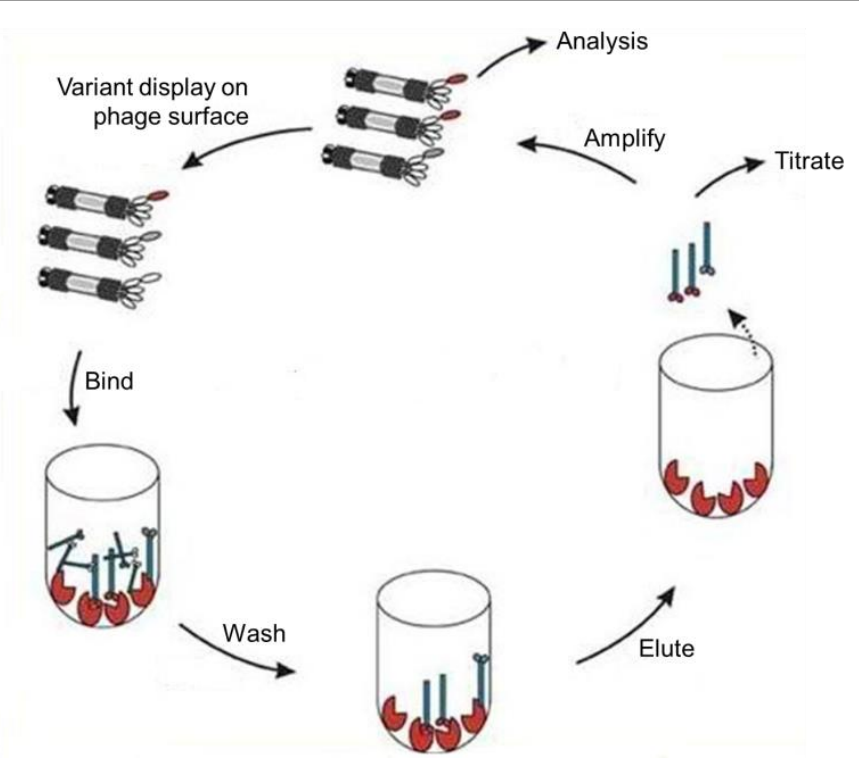

Fig. 7 Schematic illustration of a phage display cycle for peptides. The target or relevant DNA was immobilized on the surface of a microtiter plate and phages that display a protein binding to the surface of target molecule are kept while others are removed by washing. The remaining phages are then eluted and used to produce more phages (by bacterial infection with helper phage) so that a phage mixture enriched with relevant (i.e. binding) phage is obtained. ${ }^{96}$

Since the introduction of solid phase synthesis by Merrifield, ${ }^{93,}$ ${ }^{96}$ standardized and highly reproducible peptide synthesis has been enabled, resulting in intensive studies and applications (e.g. biosensors) of these synthetic molecules. Liu et al. presented an assay based on cyclic voltammetry for quantitative detection of matrilysin (MMP-7). ${ }^{41}$ Herein, peptides were immobilized on Au electrodes via self-assembly and cleaved in the presence of MMP-7 (Fig. 8a), resulting in detectable current changes. This assay was facile yet sensitive (LOD $=3.4 \mathrm{pM})$, and can be extended to detections of infectious agents. Adjémian et al. proposed a similar assay for rapid enzymatic measurements. ${ }^{42}$ Herein, peptides were immobilized on $\mathrm{Au}$ electrodes via polyethylene glycol (PEG) linkers (Fig. 8b) and detection of proteases (trypsin and $\alpha$ thrombin) was achieved on the peptide-functionalized electrodes via cyclic voltammetry. Detection of protease at 1 $\mathrm{nM}$ was demonstrated on the substrate proposed and this assay was exceptionally rapid (75\% cleavage in $1 \mathrm{~min}$ for trypsin), which could be attributed to the flexible structure of PEG linkers that allow easy access to cleavage sites for protease molecules. Nevertheless, peptide labelling (with ferrocene reporters) was required in both assays mentioned above, resulting in additional preparation procedures and increased cost. Hence, these assays were not ideal candidatures for diagnostic and clinical applications. Mannoor et al. presented a label-free electronic biosensor for quantitative detections of pathogenic bacteria via impedance spectroscopy. ${ }^{43}$ In this assay, gold microelectrode arrays functionalized with antimicrobial peptides were used to capture pathogenic bacteria such as E. coli and Salmonella and impedance changes were generated by the binding events (Fig. 8c). Significantly, the LOD achieved by this assay was around $100 \mathrm{cfu} / \mathrm{mL}$ (equivalently $1 \mathrm{\mu L}^{-1}$ ), which is within the clinically relevant range, and the detection was demonstrated to be highly selective as other bacteria (e.g. Gram-negative bacteria) did not trigger significant signals. ${ }^{97}$ Additionally, the miniaturized sensing platform exhibited great potential for portable devices that can be used for in situ detections of infectious agents. Johnson et al. proposed a peptide-based label-free impedimetric biosensor for C-reactive protein (CRP), which is a key biomarker for cardiovascular diseases. ${ }^{44}$ In this assay, peptide-functionalized electrodes were used for CRP detection based on surface plasmon resonance (SPR), electrochemical impedance spectroscopy (EIS) and cyclic voltammetry. Additionally, antibody-based assay was also demonstrated and compared with its peptide-based peer. The results revealed that the small size of peptides enabled a larger gate accessible to the probes (Fig. 8d), resulting in a sharp reduction of the charge transfer resistance. More recently, Chen et al. introduced a peptide-functionalized reduced graphene oxide FET (rGO-FET) for ultra-sensitive detection of MMP-7. In this approach, MMP-7 specifically digests negatively charged polypeptides (JR2EC) immobilized on $\mathrm{rGO}^{98}$ resulting in a significant reduction of their net charges (Fig. 8e). In this way, the proposed assay enabled label-free detection of MMP-7 at clinically relevant concentrations with LOD of $10 \mathrm{ng} / \mathrm{mL}$ in buffer and $40 \mathrm{ng} / \mathrm{mL}$ in human plasma. Additionally, the proposed assay was demonstrated to be highly selective as matrix metalloproteinase-1 (MMP-1), which is an enzyme in the same family as MMP-7, did not trigger detectable changes in $I_{d}$. 


\section{Journal Name}

\section{ARTICLE}

a

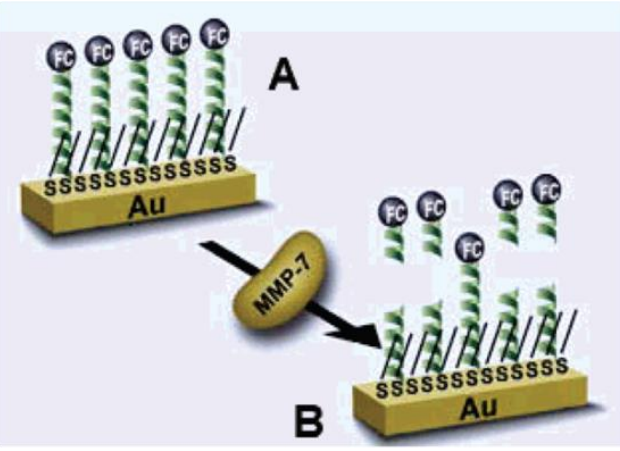

C

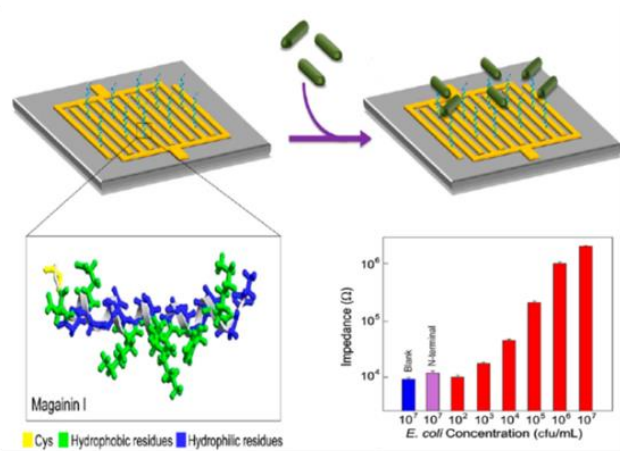

b

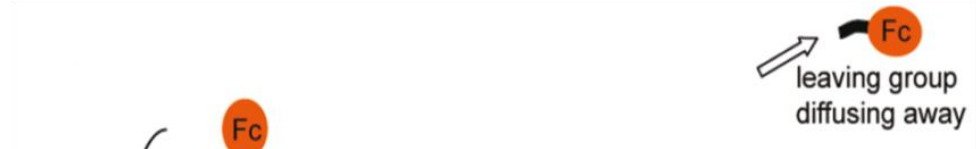

d

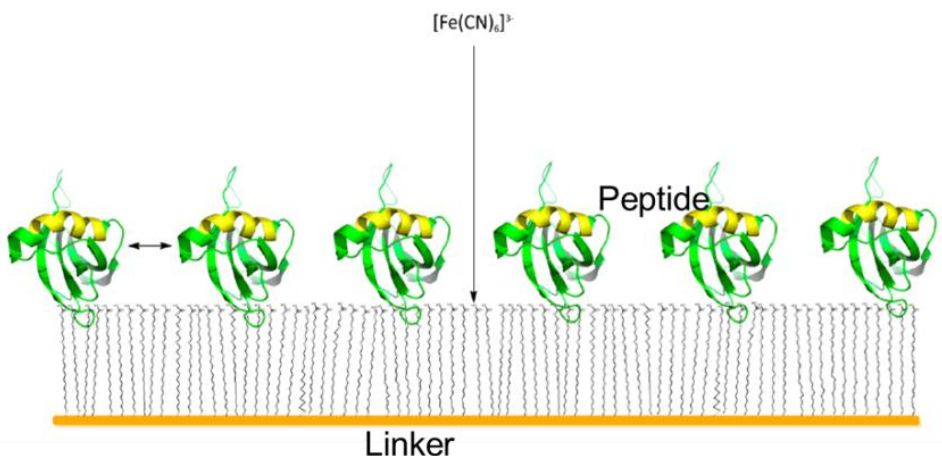

e

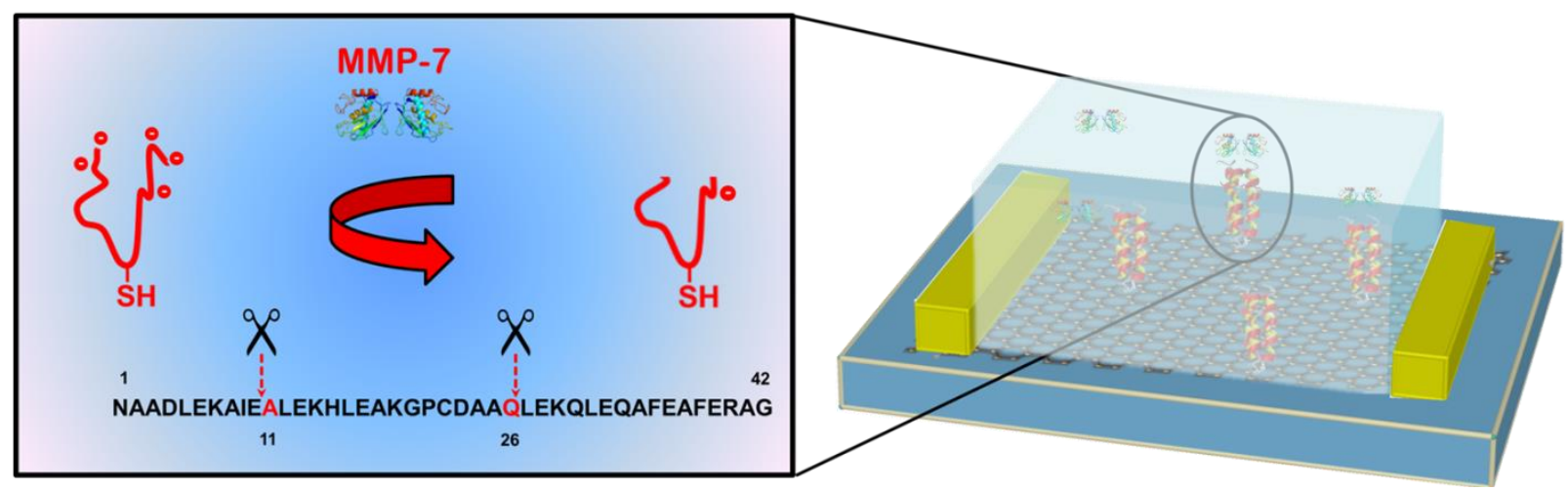

Fig. 8 (a) Schematic illustration of Matrilysin detection using peptide-functionalized Au electrodes. Cleavage of immobilized peptides was triggered in the presence of target analyte, resulting in detectable current changes. (From Liu et al., ${ }^{41}$ with permission from American Chemical Society) (b) Schematic illustration of protease detection using peptidefunctionalized Au electrodes. Reported-labelled peptides that were end-grafted on electrodes were cleaved in the presence of trypsin and thrombin. (From Adjémian et al., ${ }^{42}$ with permission from American Chemical Society) (c) Schematic illustration of bacteria detection using peptide-functionalized interdigitated microelectrode array. Detection of bacteria was achieved via binding of target cells to the immobilized peptides. (From Mannoor et al. ${ }^{43}$ with permission from National Academy of Sciences, USA) (d) Schematic illustration of CRP detection by peptide-based EIS approach. The small-sized peptide receptor allows a sharp reduction of charge transfer resistance. (From Johnson et al., ${ }^{44}$ with permission from American Chemical Society) (e) Label-free detection of MMP-7 using peptide-functionalized reduced graphene oxide FET. Negatively charged peptides immobilized on rGO were specifically digested by MMP-7 target, resulting in a significant reduction of peptide net charge. (From Chen et al., with permission from American Chemical Society)

\section{Conclusions and perspectives}

This review has described and evaluated recent advances on electronic biosensors based on non-antibody recognition elements such as liposomes, aptamers and peptides. 
Particularly, the progresses of FET-based sensing platforms were highlighted. These assays are ideal alternatives to conventional assays based on natural molecular pairs, which suffer from fragile and complicated functional structures, large molecular size and sophisticated preparation approaches. Comparisons between antibody-based assays and synthetic receptor-based ones revealed that the synthetic receptorbased assays exhibited better sensing performance in terms of sensitivity. To date, detections of various analytes (including enzyme, virus, DNA and bacteria) at clinically relevant concentrations have been demonstrated using assays based on non-antibody recognition elements.

Each category of assays shows different strengths and limitations: liposome-based assays are rapid and label-free, but suffer from tedious selection and modification process; aptamer-based assays are highly reproducible and function well in harsh environments, while aptamers' sensitivity to hydrolytic digestion by nucleases has been an intrinsic drawback; peptide-based assays are sensitive and costeffective, but suffer from poor selectivity and additional labelling processes in some cases.

Despite the great progress achieved, several issues remain to be solved before clinical applications of these assays. First, the total number of non-antibody recognition elements developed/discovered is still significantly lower than that of antibodies. This can be attributed to the fact that the discovery of these elements remains a trial-and-error process in most cases. Therefore, systematic and universal methodologies are urgently needed. Second, bio-sensing approaches based on non-antibody recognition elements have been severely limited by non-specific binding of target molecules, resulting in significantly reduced sensitivity for clinical samples. Additionally, molecular recognitions by aptamers and peptides need to be fully understood. Nevertheless, it should be noted that research in biosensors based on non-antibody recognition elements is still in its infancy and it is believed that with increasing efforts, these sensing assays will eventually be used for clinical applications and diagnostics.

\section{Acknowledgements}

This research was funded by the Institute for Sports Research, Nanyang Technological University and Loughborough University.

\section{Notes and references}

Hu Chen received his $B$. Eng. (Hons) degree from Nanyang Technological University in 2012 and is currently a Ph.D. candidate in the Institute for Sports Research, which is a joint institute by Nanyang Technological University, Singapore and Loughborough University, UK. His supervisors are Assoc Prof. Alfred I. Y. Tok from Nanyang Technological University and Dr. Mark Platt from Loughborough University. His current research interests include synthesis and bio-sensing applications of carbon nanomaterials, including carbon nanotubes and graphene, based on synthetic receptors such as liposomes, peptides and aptamers.

Jingfeng Huang received his B. Eng. (Hons) degree from Nanyang Technological University in 2008, joined Globalfoundries as a process engineer for two years before returning to NTU to pursue his Ph.D. degree under the supervisions of Assoc Prof. Alfred Tok and Prof. Myra Nimmo. He is now a postdoc research fellow in Campus for Research Excellence and Technological Enterprise (CREATE) Nanomaterials for Energy and Water Management Program, Singapore. His research focuses on synthesis of carbon-based nanomaterials and its applications in analytical chemistry, diagnostics and energy storage.

Alagappan Palaniappan received his Ph.D. degree from National University of Singapore in 2006 and is currently with the Center for Biomimetic Sensor Science, Nanyang Technological University, Singapore. His current research focuses on assay development methodologies based on optoelectronic, carbon nano-electronic, colorimetric and microgravimetric platforms for gas and biosensing applications. The main emphasis of his research is on development of point-ofcare assay devices as alternatives to current state of the art assay systems, which are usually associated with high cost and not field deployable.

Yi Wang is a research fellow at Center for Biomimetic Sensor Science (CBSS) in Nanyang Technological University, Singapore. He started his PhD at Max-Planck Institute for Polymer Research in Mainz and obtained his PhD in 2010 from Johannes Gutenberg University of Mainz, Germany. Before moved to Singapore, he worked as a scientist at Austrian Institute of Technology, Austria. His current research interests include the development of plasmonic nanostructures, novel polymers and peptide-functionalized materials for optical, electrochemical and electronic biosensors.

Bo Liedberg is a full professor and the director of Center for Biomimetic Sensor Science (CBSS) in Nanyang Technological University, Singapore. He is the author of more than 200 scientific articles, book chapters and reviews. His current research focuses on surface chemistry and biosensing in terms of molecular recognition and transduction principles. Bo Liedberg has also served as guest editor and co-editor for several sensor- and surface science oriented Journals.

Mark Platt received his B.E. degree from University of Salford in 2001 and Ph.D. degree from University of Manchester under the supervision of Prof. Robert Dryfe in 2004. He then worked as a postdoc in institutions in USA and UK, before taking up a faculty position in Loughborough University. His current research focuses on material interfaces and analytical chemistry for development of diagnostic tools. 
Alfred I. Y. Tok received his B. Eng. (Hons) degree from the Queensland University of Technology in 1995 and Ph.D. degree from Nanyang Technological University in 2000. Dr. Tok is currently an associate professor and deputy director of the Institute for Sports Research, Nanyang Technological University. His current research focuses are carbon nanomaterials for bio-sensing applications and synthesis of functional nanomaterials using atomic layer deposition.

1. A. P. Turner, Chemical Society Reviews, 2013, 42, 31843196.

2. D. W. H. Fam, A. I. Y. Tok, A. Palaniappan, P. Nopphawan, A. Lohani and S. Mhaisalkar, Sensors and Actuators B: Chemical, 2009, 138, 189-192.

3. J. Connelly and A. Baeumner, Analytical and Bioanalytical Chemistry, 2012, 402, 117-127.

4. Y. Wang, J. Dostálek and W. Knoll, Biosensors and Bioelectronics, 2009, 24, 2264-2267.

5. M. Thakur and K. Ragavan, Journal of Food Science and Technology, 2013, 50, 625-641.

6. J. Wang, Chemical Reviews, 2008, 108, 814-825.

7. Y. Wang, X. Liu, J. Zhang, D. Aili and B. Liedberg, Chemical Science, 2014, 5, 2651-2656.

8. J. Huang, H. Chen, W. Niu, D. W. H. Fam, A. Palaniappan, M. Larisika, S. H. Faulkner, C. Nowak, M. A. Nimmo, B. Liedberg and A. I. Y. Tok, RSC Advances, 2015, 5, 3924539251.

9. N. Aroonyadet, X. Wang, Y. Song, H. Chen, R. J. Cote, M. E. Thompson, R. H. Datar and C. Zhou, Nano Letters, 2015, 15, 1943-1951.

10. J. Huang, D. Fam, Q. He, H. Chen, D. Zhan, S. H. Faulkner, M. A. Nimmo and A. I. Yoong Tok, Journal of Materials Chemistry C, 2014, 2, 109-114.

11. G. Liu, Y. Lin, V. Ostatna and J. Wang, Chemical Communications, 2005, 3481-3483.

12. B. L. Allen, P. D. Kichambare and A. Star, Advanced Materials, 2007, 19, 1439-1451.

13. U. Brand, L. Brandes, V. Koch, T. Kullik, B. Reinhardt, F. Rüther, T. Scheper, K. Schügerl, S. Wang, X. Wu, R. Ferretti, S. Prasad and D. Wilhelm, Appl Microbiol Biotechnol, 1991, 36, 167-172.

14. A. Palaniappan, W. H. Goh, D. W. H. Fam, G. Rajaseger, C. E. Z. Chan, B. J. Hanson, S. M. Moochhala, S. G. Mhaisalkar and B. Liedberg, Biosensors and Bioelectronics, 2013, 43, 143-147.

15. D. Pressman and A. L. Grossberg, Structural basis of antibody specificity, Springer, 1970.

16. J. Zhou, M. Battig and Y. Wang, Analytical and Bioanalytical Chemistry, 2010, 398, 2471-2480.

17. J. L. Pellequer and M. H. V. Van Regenmortel, Molecular Immunology, 1993, 30, 955-958.

18. S. Cheng, S. Hideshima, S. Kuroiwa, T. Nakanishi and T. Osaka, Sensors and Actuators B: Chemical, 2015, 212, 329334.

19. M. Gebauer and A. Skerra, Current Opinion in Chemical Biology, 2009, 13, 245-255.

20. D. E. Steinmeyer and E. L. McCormick, Drug Discovery Today, 2008, 13, 613-618.

21. Q. Liu and B. J. Boyd, Analyst, 2013, 138, 391-409.

22. X. Ke, M. Xenia, M. N. Barbara, Z. Eugene, D. Mitra and A. S. Michael, Nanotechnology, 2014, 25, 205501.
23. Q. Liu, J. Wang and B. J. Boyd, Talanta, 2015, 136, 114 127.

24. S. Song, L. Wang, J. Li, C. Fan and J. Zhao, TrAC Trends in Analytical Chemistry, 2008, 27, 108-117.

25. E. Pazos, O. Vazquez, J. L. Mascarenas and M. Eugenio Vazquez, Chemical Society Reviews, 2009, 38, 3348-3359.

26. G. L. Damhorst, C. E. Smith, E. M. Salm, M. M. Sobieraj, H. $\mathrm{Ni}, \mathrm{H}$. Kong and R. Bashir, Biomedical Microdevices, 2013, 15, 895-905.

27. N. Wongkaew, P. He, V. Kurth, W. Surareungchai and A. J. Baeumner, Analytical and Bioanalytical Chemistry, 2013, 405, 5965-5974.

28. M. A. Taylor, M. N. Jones, P. M. Vadgama and S. P. J. Higson, Biosensors and Bioelectronics, 1995, 10, 251-260.

29. M. A. Taylor, M. N. Jones, P. M. Vadgama and S. P. J. Higson, Biosensors and Bioelectronics, 1997, 12, 467-477.

30. J. S. Graça, R. F. de Oliveira, M. L. de Moraes and M. Ferreira, Bioelectrochemistry, 2014, 96, 37-42.

31. J. Yan, H. Guan, J. Yu and D. Chi, Pesticide Biochemistry and Physiology, 2013, 105, 197-202.

32. W. Zhang, H. Tang, P. Geng, Q. Wang, L. Jin and Z. Wu, Electrochemistry Communications, 2007, 9, 833-838.

H. Chen, S. K. Lim, P. Chen, J. Huang, Y. Wang, A. Palaniappan, M. Platt, B. Liedberg and A. I. Y. Tok, Physical Chemistry Chemical Physics, 2015, 17, 3451-3456.

34. J. Fritz, E. B. Cooper, S. Gaudet, P. K. Sorger and S. R. Manalis, Proceedings of the National Academy of Sciences, 2002, 99, 14142-14146.

35. M. Zayats, Y. Huang, R. Gill, C.-a. Ma and I. Willner, Journal of the American Chemical Society, 2006, 128, 13666-13667.

36. K. Maehashi, T. Katsura, K. Kerman, Y. Takamura, K. Matsumoto and E. Tamiya, Analytical Chemistry, 2007, 79, 782-787.

37.

A. Rahim Ruslinda, K. Tanabe, S. Ibori, X. Wang and H. Kawarada, Biosensors and Bioelectronics, 2013, 40, 277282.

38. T. Goda and Y. Miyahara, Biosensors and Bioelectronics, 2012, 32, 244-249.

39. T. Goda and Y. Miyahara, Biosensors and Bioelectronics, 2013, 45, 89-94.

40. T. Goda, D. Higashi, A. Matsumoto, T. Hoshi, T. Sawaguchi and Y. Miyahara, Biosensors and Bioelectronics, 2015, 73, 174-180.

41. G. Liu, J. Wang, D. S. Wunschel and Y. Lin, Journal of the American Chemical Society, 2006, 128, 12382-12383.

J. Adjémian, A. Anne, G. Cauet and C. Demaille, Langmuir, 2010, 26, 10347-10356.

M. S. Mannoor, S. Zhang, A. J. Link and M. C. McAlpine, Proceedings of the National Academy of Sciences, 2010, 107, 19207-19212.

44. A. Johnson, Q. Song, P. Ko Ferrigno, P. R. Bueno and J. J. Davis, Analytical Chemistry, 2012, 84, 6553-6560.

45. S. K. Lim, H.-P. de Hoog, A. N. Parikh, M. Nallani and B. Liedberg, Polymers, 2013, 5, 1102-1114.

B. M. Discher, Y.-Y. Won, D. S. Ege, J. C. M. Lee, F. S. Bates, D. E. Discher and D. A. Hammer, Science, 1999, 284, 11431146.

47. L. Zhang and A. Eisenberg, Journal of the American Chemical Society, 1996, 118, 3168-3181.

D. A. LaVan, T. McGuire and R. Langer, Nature Biotechnology, 2003, 21, 1184-1191. 
49

B.-W. Park, D.-Y. Yoon and D.-S. Kim, Biosensors and Bioelectronics, 2010, 26, 1-10.

50. D. Voccia, F. Bettazzi and I. Palchetti, in Sensors and Microsystems, eds. C. Di Natale, V. Ferrari, A. Ponzoni, G. Sberveglieri and M. Ferrari, Springer International Publishing, 2014, vol. 268, ch. 34, pp. 179-182.

51. A. Sharma and U. S. Sharma, International Journal of Pharmaceutics, 1997, 154, 123-140.

52. Y. Gerelli, S. Barbieri, M. T. Di Bari, A. Deriu, L. Cantù, P. Brocca, F. Sonvico, P. Colombo, R. May and S. Motta, Langmuir, 2008, 24, 11378-11384.

53. T. M. Taylor, J. Weiss, P. M. Davidson and B. D. Bruce, Critical Reviews in Food Science and Nutrition, 2005, 45, 587-605.

54. V. Vamvakaki and N. A. Chaniotakis, Biosensors and Bioelectronics, 2007, 22, 2848-2853.

55. E. H. Oh, S. H. Lee, H. J. Ko and T. H. Park, Sensors and Actuators B: Chemical, 2014, 198, 188-193.

56. S. Ahn-Yoon, T. R. DeCory and R. A. Durst, Analytical and Bioanalytical Chemistry, 2004, 378, 68-75.

57. M. Rangin and A. Basu, Journal of the American Chemical Society, 2004, 126, 5038-5039.

58. K. L. Diehl and E. V. Anslyn, Chemical Society Reviews, 2013, 42, 8596-8611.

59. X. Chen, G. Zhou, X. Peng and J. Yoon, Chemical Society Reviews, 2012, 41, 4610-4630.

$60 . \quad$ J. T. Mason, L. Xu, Z.-m. Sheng and T. J. O'Leary, Nature Biotechnology, 2006, 24, 555-557.

61. C. Chen and Q. Wang, American Journal of Nano Research and Application, 2015, 3, 13-17.

62. J. Huang, L. Wang, C. Shi, Y. Dai, C. Gu and J. Liu, Sensors and Actuators B: Chemical, 2014, 196, 567-573.

63. A. D. Ellington and J. W. Szostak, Nature, 1990, 346, 818822.

64. C. Tuerk and L. Gold, Science, 1990, 249, 505-510.

65. T. Hermann and D. J. Patel, Science, 2000, 287, 820-825.

66. C. Ferreira, C. Matthews and S. Missailidis, Tumor Biology, 2006, 27, 289-301.

67. E. W. M. Ng, D. T. Shima, P. Calias, E. T. Cunningham, D. R. Guyer and A. P. Adamis, Nature Review Drug Discovery, 2006, 5, 123-132.

68. S. Centi, S. Tombelli, M. Minunni and M. Mascini, Analytical Chemistry, 2007, 79, 1466-1473.

69.

70.

S. D. Jayasena, Clinical Chemistry, 1999, 45, 1628-1650.

J. C. Rohloff, A. D. Gelinas, T. C. Jarvis, U. A. Ochsner, D. J. Schneider, L. Gold and N. Janjic, Mol Ther Nucleic Acids, 2014, 3, e201.

71. B. S. Ferguson, D. A. Hoggarth, D. Maliniak, K. Ploense, R. J. White, N. Woodward, K. Hsieh, A. J. Bonham, M. Eisenstein, T. E. Kippin, K. W. Plaxco and H. T. Soh, Science Translational Medicine, 2013, 5, 213ra165-213ra165.

72. M. Platt, W. Rowe, D. C. Wedge, D. B. Kell, J. Knowles and P. J. R. Day, Analytical Biochemistry, 2009, 390, 203-205.

73. W. Rowe, M. Platt, D. C. Wedge, P. J. R. Day, D. B. Kell and J. D. Knowles, Physical Biology, 2010, 7, 036007.

74.

E. L. Blundell, L. J. Mayne, E. R. Billinge and M. Platt, Analytical Methods, 2015.

75. J. F. Lee, G. M. Stovall and A. D. Ellington, Current Opinion in Chemical Biology, 2006, 10, 282-289.

76. A. A. Lubin, R. Y. Lai, B. R. Baker, A. J. Heeger and K. W. Plaxco, Analytical Chemistry, 2006, 78, 5671-5677.
77.

78.

79.

80.

Communications, 2014, 50, 3476-3479.

M. Mammen, S.-K. Choi and G. M. Whitesides, Angewandte Chemie International Edition, 1998, 37, 2754-2794.

82. D. Aili, R. Selegård, L. Baltzer, K. Enander and B. Liedberg, Small, 2009, 5, 2445-2452.

83. D. J. Craik, D. P. Fairlie, S. Liras and D. Price, Chemical Biology \& Drug Design, 2013, 81, 136-147.

84. D. Aili, K. Enander, J. Rydberg, I. Lundström, L. Baltzer and B. Liedberg, Journal of the American Chemical Society, 2006, 128, 2194-2195.

85. Z. Wang, P. Huang, A. Bhirde, A. Jin, Y. Ma, G. Niu, N. Neamati and X. Chen, Chemical Communications, 2012, 48, 9768-9770.

86.

W. Su, M. Cho, J.-D. Nam, W.-S. Choe and Y. Lee, Biosensors and Bioelectronics, 2013, 48, 263-269.

87. J. Lei and H. Ju, Chemical Society Reviews, 2012, 41, 21222134.

88. S. K. Lim, P. Chen, F. L. Lee, S. Moochhala and B. Liedberg, Analytical Chemistry, 2015, 87, 9408-9412.

89.

G. J. Cotton, B. Ayers, R. Xu and T. W. Muir, Journal of the American Chemical Society, 1999, 121, 1100-1101.

90. S. Pavan and F. Berti, Anal Bioanal Chem, 2012, 402, 30553070.

R. Pearlman and Y. J. Wang, Stability and characterization of protein and peptide drugs: case histories, Springer Science \& Business Media, 2013.

92. E. Schröder and K. Lübke, The Peptides: Methods of peptide synthesis, Elsevier, 2014.

93. R. B. Merrifield, Journal of the American Chemical Society, $1963,85,2149-2154$.

94. N. V. Kulagina, K. M. Shaffer, G. P. Anderson, F. S. Ligler and C. R. Taitt, Analytica Chimica Acta, 2006, 575, 9-15. J. Slaninová, V. Mlsová, H. Kroupová, L. Alán, T. Tůmová, L. Monincová, L. Borovičková, V. Fučík and V. Čeřovský, Peptides, 2012, 33, 18-26.

96. R. B. Merrifield, Biochemistry, 1964, 3, 1385-1390.

97. S. D. Manning, Escherichia coli infections, Infobase Publishing, 2010.

P. Chen, R. Selegard, D. Aili and B. Liedberg, Nanoscale, 2013, 5, 8973-8976. 